\title{
Hubungan antara Karakteristik Pasien dan Terapi terhadap Nilai Retensi di RSJ Menur Surabaya
}

\section{(Relationship between Patient Characteristics and Therapy to Retention Rate at Menur Psychiatric Hospital Surabaya)}

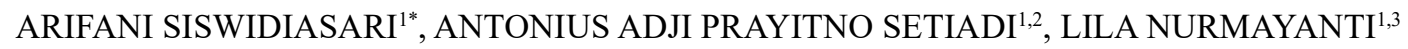 \\ ${ }^{1}$ Departemen Farmasi Klinis dan Komunitas, Fakultas Farmasi Universitas Surabaya, Jalan Raya \\ Kali Rungkut Surabaya, 60293, Indonesia \\ ${ }^{2}$ Pusat Informasi Obat dan Layanan Kefarmasian (PIOLK), Gedung FF Lantai 5, Fakultas Farmasi \\ Universitas Surabaya, Surabaya, 60293, Indonesia \\ ${ }^{3}$ Rumah Sakit Jiwa Menur, Manyar Sabrangan, Mulyorejo, Jalan Raya Menur No. 120, Kertajaya, \\ Gubeng, Surabaya, 60282, Indonesia \\ *Penulis korespondensi, Hp : 087761118833 \\ e-mail: arifanisiswi@gmail.com
}

Diterima 2 Juli 2018, Disetujui 6 Maret 2019

\begin{abstract}
Abstrak: Program terapi rumatan metadon (PTRM) merupakan salah satu upaya pemerintah untuk menangani penyalahgunaan narkotika, psikotropika, dan zat adiktif lainnya (NAPZA) di Indonesia. Parameter keberhasilan PTRM dapat dilihat dari nilai retensi yang merupakan lamanya pasien dalam menjalani terapi rumatan metadon setelah mendapatkan terapi stabilisasi (pemberian metadon selama 6 minggu atau 42 hari). Penelitian ini bertujuan untuk mengetahui hubungan antara karakteristik pasien dan terapi terhadap nilai retensi pada PTRM di RSJ Menur Surabaya. Penelitian dengan rancangan cross-sectional ini dilakukan secara retrospektif dengan melihat data rekam medis pasien pecandu NAPZA. Penelitian ini melibatkan 41 subyek yang telah dipilih secara consecutive sampling. Data karakteristik pasien dan terapi dianalisis secara deskriptif dan hubungan variabel dengan nilai retensi dianalisis menggunakan korelasi Spearman. Hasil penelitian menunjukkan nilai retensi pada 6 bulan (4,9\%), 9 bulan (12,2\%), 12 bulan (19,5\%), 24 bulan (26,8\%), 36 bulan (26,8\%), 48 bulan (4,9\%), dan 60 bulan (4,9\%). Berdasarkan korelasi Spearman, dosis rumatan terkecil merupakan variabel yang menunjukkan korelasi yang signifikan terhadap nilai retensi $(\mathrm{p}=0,036$ dengan korelasi cukup $\mathrm{r}=$ $-0,328$ ). Oleh sebab itu, pemilihan dosis terkecil pada pasien yang menjalani terapi rumatan metadon perlu menjadi perhatian khusus untuk meningkatkan keberhasilan PTRM, yang dalam penelitian ini ditunjukkan dari nilai retensi.
\end{abstract}

Kata kunci: Metadon, dosis, nilai retensi, PTRM, NAPZA.

\begin{abstract}
Methadone maintenance therapy program (MMTP) is the government's efforts to reduce drug abuse in Indonesia. The MMTP success parameters can be seen from the retention rate which is the length of time patients undergo methadone maintenance therapy after receiving stabilization therapy (administration of methadone for 6 weeks or 42 days). This study aimed to determine the relationship of the patients characteristics and therapy to the retention rate in Menur Psychiatric Hospital Surabaya. This cross-sectional study was conducted retrospectively by reviewed the patient's medical record and involved 41 subjects who were selected by consecutive sampling. Patient characteristics and therapy was analyzed descriptively and the variables relationship with retention rate was analyzed by using Spearman's correlation test. The results showed the retention rate at 6 months $(4.9 \%), 9$ months $(12.2 \%)$, 12 months (19.5\%), 24 months (26.8\%), 36 months (26.8\%), 48 months (4.9\%), and 60 months (4.9\%). According to Spearman's correlation test, the smallest maintenance dose shows a significant correlation to the retention rate $(p=0.036$ with sufficient correlation $r=-0.382)$. Therefore, the selection of the smallest dose in patients undergoing MMTP needs a particular concern to increase the successfulness of this program, which is indicated by the retention rate in this study.
\end{abstract}

Keywords: Methadone, dose, retention rate, MMTP, drugs. 


\section{PENDAHULUAN}

MASALAH penyalahgunaan narkotika, psikotropika dan zat adiktif lainnya (NAPZA) atau dikenal dengan istilah lain sebagai narkotika dan obat berbahaya (NARKOBA) merupakan salah satu masalah yang sangat serius karena dapat mengancam masa depan bangsa di seluruh negara maju maupun di negara berkembang ${ }^{(1)}$. Jumlah kasus narkoba di Indonesia dari tahun ke tahun mengalami peningkatan baik pada konteks pengguna, mata rantai yang berkaitan dengan barang haram tersebut (produsen, bandar, pemakai) maupun jumlah narkoba itu sendiri yang semakin beragam ${ }^{(2)}$.

Penggunaan narkoba disuntik atau Injecting Drug User (IDU) merupakan salah satu cara penggunaan narkoba yang paling berisiko yang dapat menimbulkan penularan infeksi HIV/AIDS, hepatitis B, hepatitis C dan penyakit infeksi lainnya yang ditularkan melalui darah atau cairan tubuh yang disebabkan penggunaan jarum suntik yang bergantian dan tidak steril ${ }^{(3)}$. Salah satu narkoba yang digunakan dengan cara disuntik adalah heroin. Oleh karena itu, program pengurangan dampak buruk dari penularan NAPZA suntik (harm reduction) mutlak diperlukan. Salah satu kegiatan pendekatan harm reduction adalah terapi substitusi dengan pemberian obat oral metadon sebagai salah satu cara untuk mencoba melepaskan pecandu dari ketergantungan NAPZA ${ }^{(4,5)}$.

Pada kurun waktu 2006-2010, data resmi dari Badan Narkotika Nasional juga mencatat prevalensi penyalahgunaan narkoba $1,99 \%$ dari jumlah penduduk Indonesia pada tahun 2008, yang artinya mencapai 3,6 juta orang. Selanjutnya, berdasarkan hasil penelitian BNN yang bekerjasama dengan Pusat Penelitian Kesehatan Universitas Indonesia (Puslitkes UI) tahun 2011, diketahui bahwa angka prevalensi penyalahguna narkoba telah mencapai $2,2 \%$ dari total populasi penduduk (berusia 10-60 tahun) atau sekitar 4 juta orang. Hal ini mengalami peningkatan $0,21 \%$ bila dibandingkan tahun $2008(1,99 \%)$ atau sekitar 3,6 juta orang. Tahun 2015, angka prevalensi penyalahgunaan narkoba mencapai $2,8 \%$ dari total penduduk Indonesia atau sekitar 5,1 juta jiwa ${ }^{(2)}$.

Pemerintah menyelenggarakan program terapi rumatan metadon (PTRM), melalui Menteri Kesehatan Republik Indonesia Nomor 57 Tahun 2013 tentang penetapan rumah sakit pengampu dan satelit program terapi rumatan metadon serta pedoman program terapi rumatan metadon, telah menetapkan beberapa rumah sakit di Indonesia, terdapat 25 rumah sakit pengampu program terapi rumatan metadon dan terdapat 31 satelit pelayanan program terapi rumatan metadon yang terdiri dari beberapa puskesmas dan lapas/rutan. Berdasarkan hasil uji coba program terapi rumatan metadon di RS Sanglah dan Rumah Sakit Ketergantungan Obat (RSKO), diperoleh hasil yang positif yaitu perbaikan kualitas hidup dari segi fisik, psikologi, hubungan sosial dan lingkungan, penurunan angka kriminalitas, penurunan depresi dan perbaikan kembali ke aktivitas sebagai anggota masyarakat ${ }^{(5)}$.

Terapi substitusi yang dilakukan dengan cara memberikan obat oral metadon ini terbukti cukup efektif dalam meningkatkan kesejahteraan pasien agar dapat kembali melakukan aktivitas pekerjaan dalam masyarakat. Salah satu program substitusi adalah PTRM. PTRM sendiri memiliki dua tujuan pilihan. Tujuan pertama yaitu untuk membantu pecandu agar berhenti menggunakan narkoba yang diganti dengan metadon yang dikurangi secara bertahap selama jangka waktu tertentu sedangkan tujuan kedua yaitu untuk mengurangi dampak buruk yang diakibatkan oleh penggunaan NAPZA suntikan ${ }^{(4)}$. PTRM dipercaya paling bermanfaat untuk menangani ketergantungan opioid serta mengurangi bahaya akibat penggunaannya.

Metadon merupakan obat sintetis yang termasuk golongan opiat yang diberikan dalam bentuk sediaan oral kepada pasien sebagai terapi pengganti adiksi opioid. Tujuan pemberian metadon adalah untuk memberikan kesempatan kepada penggunanya untuk mengubah hidupnya menjadi lebih stabil, mengurangi risiko terkait penggunaan narkoba suntik dan juga mengurangi kejahatan yang sering terkait dengan kecanduan ${ }^{(6)}$. Metadon digunakan sebagai obat yang aman dan efektif untuk menarik diri pecandu dari heroin tetapi bukanlah untuk berhenti( ${ }^{(7)}$. Dosis awal metadon berada di kisaran 20-40 mg dan berkisar $\leq 40 \mathrm{mg}$ pada akhir minggu pertama ${ }^{(8)}$. Kontinuitas pengobatan sangat penting untuk menunjukkan sedikit atau tidak adanya perbaikan ${ }^{(9)}$. Pasien yang sudah mencapai stabilisasi yang cukup dengan dosis metadon yang tepat, maka pasien dapat bekerja secara normal, mengurangi tindakan kekerasan dan menurunkan penyebaran HIV dengan menurunkan penggunaan jarum suntik. Pasien dengan dosis stabilisasi dalam terapi ini juga dapat diikutsertakan dalam konseling dan intervensi perilaku lainnya untuk mempercepat perbaikan dan rehabilitasi ${ }^{(10)}$.

Nilai retensi adalah lamanya pasien didalam menjalani terapi rumatan metadon setelah mendapatkan terapi stabilisasi (pemberian metadon selama 6 minggu atau 42 hari) yang merupakan salah satu indikator dalam terapi rumatan metadon. Nilai retensi (retention rate) bisa digunakan untuk mengukur keberhasilan PTRM. Penelitian yang dilakukan Pahlemy, menemukan retention rate pasien terapi metadon di Rumah Sakit Umum Pusat Fatmawati 
adalah $46,8 \%$ pada 1 tahun pengobatan terapi metadon $^{(11)}$. Sedangkan penelitian dari Aprilya dkk., retention rate pasien terapi metadon di Puskesmas Kassi-Kassi adalah 93,3\% selama 6 bulan pengobatan terapi metadon ${ }^{(12)}$. Sejalan dengan penelitian dari Rahayu dan Syarif, retention rate pasien terapi metadon di Puskesmas Kecamatan Tebet adalah 84,6\% pada 1 tahun pengobatan terapi metadon ${ }^{(13)}$.

Jenis prediktor retensi antara lain sebagai berikut: karakteristik pasien yaitu usia, jenis kelamin, riwayat kriminal, riwayat penggunaan opioid, penyesuaian psikologikal, pekerjaan, tinggal dengan keluarga atau partner, penggunaan alkohol, penggunaan banyak obat-obatan lain serta motivasi dan ekspektasi terhadap terapi dan karakteristik terapi yaitu dosis metadon, filosofi terapi, pelayanan tambahan, aksesibilitas klinik, biaya terapi, dosis bawa pulang serta penilaian cepat ${ }^{(14)}$.

PTRM yang diberikan pada pasien pecandu NAPZA di Rumah Sakit Jiwa (RSJ) Menur Surabaya belum pernah dipublikasikan dalam bentuk hasil penelitian. Di mana Rumah Sakit Jiwa Menur Surabaya yang merupakan rumah sakit khusus dengan klasifikasi kelas A. Dengan mengetahui faktor-faktor yang mempengaruhi nilai retensi pada pasien pecandu NAPZA yang diperoleh diharapkan dapat menjadi evidence based pada terapi berikutnya. Berdasarkan uraian tersebut maka perlu dilakukan penelitian terkait dengan karakteristik pasien dan terapi terhadap nilai retensi dalam menjalankan PTRM. Oleh karena itu peneliti tertarik untuk melakukan penelitian dengan judul "Hubungan antara Karakteristik Pasien dan Terapi terhadap Nilai Retensi pada Program Terapi Rumatan Metadon di RSJ Menur Surabaya". Dalam penelitian ini, pengambilan data dilakukan di RSJ Menur Surabaya dari bulan Oktober-Desember 2017.

\section{BAHAN DAN METODE}

BAHAN. Data rekam medis pasien rawat jalan yang pertama kali mengikuti PTRM di RSJ Menur Surabaya dari bulan Januari 2012 - Desember 2016 yang memenuhi kriteria inklusi dan tidak masuk kriteria eksklusi.

METODE. Penelitian ini merupakan penelitian observasional dengan rancangan cross-sectional yang dilakukan secara retrospektif pada pasien pecandu NAPZA di RSJ Menur Surabaya. Rancangan crosssectional merupakan rancangan penelitian dengan melakukan pengukuran atau pengamatan pada saat yang bersamaan atau melakukan pemeriksaan status paparan dan status penyakit pada titik yang sama. Pengambilan data yang dilakukan secara retrospektif yaitu dari data sekunder dengan cara melihat rekam medis pasien yang terdaftar dalam PTRM di RSJ Menur Surabaya.

Sampel penelitian ini adalah semua data rekam medis pasien rawat jalan yang pertama kali mengikuti PTRM di RSJ Menur Surabaya dari bulan Januari 2012 - Desember 2016 yang memenuhi kriteria inklusi dan tidak masuk kriteria eksklusi.

Kriteria inklusi yaitu pasien pecandu NAPZA yang menjalani program terapi rumatan metadon (PTRM) di RSJ Menur Surabaya pada bulan Januari 2012 - Desember 2016, pasien pecandu NAPZA yang menerima terapi rumatan metadon untuk pertama kalinya di RSJ Menur Surabaya pada bulan Januari 2012 - Desember 2016, pasien berada dalam terapi lebih dari 6 minggu (42 hari), berusia 18 tahun atau lebih dan sudah pernah mencoba berhenti menggunakan opioid minimal satu kali. Kriteria eksklusi yaitu pasien PTRM yang mendapatkan terapi obat anti retroviral (ARV) dan anti tuberkulosis (OAT), data rekam medis pasien yang tidak lengkap/pasien pindahan/pasien transit, pasien dengan penyakit fisik berat, wanita hamil dan menyusui.

Metode pengambilan sampel dilakukan secara consecutive sampling yaitu pengambilan semua data rekam medis pasien yang ada di instalasi rawat jalan poliklinik rumatan metadon di RSJ Menur Surabaya yang sesuai dengan kriteria inklusi dan eksklusi dalam penelitian ini. Berdasarkan data yang diperoleh total rekam medis pasien yang mengikuti program terapi rumatan metadon PTRM di RSJ Menur Surabaya adalah 41 pasien.

Teknik Pengumpulan Data. Data pasien pada penelitian ini dikumpulkan dari rekam medis pasien pecandu NAPZA yang mengikuti PTRM di RSJ Menur Surabaya. Dimana data tersebut dimasukkan dalam lembar pengumpulan data yang meliputi antara lain: 1) Data demografi yaitu meliputi: nomor rekam medis pasien, nama pasien, jenis kelamin, usia, tingkat pendidikan, pekerjaan, status pernikahan, riwayat hukum, riwayat penggunaan zat aktif, lama penggunaan opioid dan riwayat dosis terlewat; 2) Data pengobatan yaitu meliputi: dosis awal, dosis rumatan terkecil, dosis rumatan terbesar, dosis rumatan rata-rata dan dosis bawa pulang (THD) rata-rata yang diberikan kepada pasien dalam mengikuti PTRM. Data hasil penelitian ditabulasi berdasarkan analisis deskriptif. Hubungan antara variabel dianalisis menggunakan korelasi Spearman. Hubungan signifikan antara variabel ditandai dengan nilai $\mathrm{p}<0,05$.

\section{HASIL DAN PEMBAHASAN}

Nilai Retensi Pasien pada Terapi Rumatan Metadon di RSJ Menur Surabaya. Nilai retensi 
adalah lamanya pasien didalam menjalani terapi rumatan metadon setelah mendapatkan terapi stabilisasi (pemberian metadon selama 6 minggu atau 42 hari) yang merupakan salah satu indikator dalam mengukur keberhasilan dari PTRM. Penghitungan nilai retensi dimulai pada hari ke-43 (hari pertama setelah fase stabilisasi). Nilai retensi dipantau pada bulan ke-6, 9, 12, 24, 36, 48, dan 60 setelah fase stabilisasi. Detail nilai retensi pasien dapat dilihat pada Tabel 1.

Nilai retensi rata-rata pasien terapi rumatan metadon adalah 604 hari dengan range 95-1529 hari. Retention rate pasien terbesar dalam penelitian ini adalah pada 24 bulan $26,8 \%$; 36 bulan $26,8 \%$; dan 12 bulan $19,5 \%$. Penelitian serupa yang ditemukan yaitu dengan kisaran $40 \%{ }^{(15)}$. Hal ini kemungkinan disebabkan oleh dosis terbesar rata-rata pada penelitian tersebut lebih kecil yaitu $44 \mathrm{mg}$ dibandingkan dosis terbesar rata-rata pada penelitian ini yaitu $78,17 \mathrm{mg}$. Penelitian yang dilakukan Pahlemy, menemukan retention rate pasien terapi rumatan metadon sebesar $46,8 \%$ selama 1 tahun atau lebih pengobatan ${ }^{(11)}$. Penelitian serupa juga dilakukan Rahayu dan Syarif, menemukan retention rate pasien terapi rumatan metadon sebesar $84,6 \%$ pada 1 tahun pengobatan ${ }^{(13)}$.

Kunci keberhasilan dari terapi rumatan metadon ini adalah nilai dari retensi pasiennya. Pada beberapa penelitian menunjukkan outcome yang baik dari terapi ketergantungan obat berhubungan dengan lama terapi pasien. Sebagian besar pasien yang keluar dari terapi metadon sebelum waktu 1 tahun akan kembali menggunakan heroin (relapse opiate) ${ }^{(16)}$. Retensi dalam terapi rumatan metadon memiliki hubungan dengan peningkatan produktifitas sosial, berkurangnya tingkat kriminal, dan tingkat mortalitas. Jumlah persentase pasien yang bekerja, melanjutkan sekolah, dan bekerja di rumah tangga meningkat ${ }^{(14)}$.

Hubungan Dosis Metadon terhadap Nilai Retensi dengan Analisis Korelasi Spearman. Pada dosis rumatan terkecil dengan retensi terdapat korelasi yang signifikan nilai $\mathrm{p}=0,036$ dengan korelasi cukup $r=-0,328$ sedangkan pada dosis awal, dosis rumatan terbesar, dosis rumatan rata-rata dan dosis bawa pulang (THD) rata-rata, tidak ada korelasi yang signifikan. Detail hubungan dosis pasien dapat dilihat pada Tabel 2.

Berdasarkan hasil analisis korelasi Spearman, menunjukkan tidak ada hubungan yang signifikan antara dosis awal $(\mathrm{p}=0,290$ atau $\mathrm{p}>0,05)$ dengan korelasi sangat lemah $(r=-0,169)$, dosis rumatan terbesar $(\mathrm{p}=0,791$ atau $\mathrm{p}>0,05)$ dengan korelasi sangat lemah $(\mathrm{r}=0,043)$, dosis rumatan rata-rata $(\mathrm{p}=0,967$ atau $\mathrm{p}>0,05)$ dengan korelasi sangat lemah $(\mathrm{r}=-0,007)$ dan dosis bawa pulang (THD) rata-rata
Tabel 1. Nilai retensi pasien pada terapi rumatan metadon di RSJ Menur Surabaya.

\begin{tabular}{cccc}
\hline Retensi & Frekuensi & Persentase (\%) & Jumlah \\
\hline 6 bulan & 2 & 4,9 & 41 \\
9 bulan & 5 & 12,2 & 39 \\
12 bulan & 8 & 19,5 & 34 \\
24 bulan & 11 & 26,8 & 26 \\
36 bulan & 11 & 26,8 & 15 \\
48 bulan & 2 & 4,9 & 4 \\
60 bulan & 2 & 4,9 & 2 \\
\hline
\end{tabular}

Tabel 2. Hubungan dosis metadon terhadap nilai retensi dengan analisis korelasi Spearman.

\begin{tabular}{|c|c|c|}
\hline Deskripsi dosis & Nilai $r$ & Signifikansi \\
\hline Dosis awal & $r=-0,169$ & $\mathrm{p}=0,290$ \\
\hline Dosis rumatan terkecil & $r=-0,328$ & $\mathrm{p}=0,036$ \\
\hline Dosis rumatan terbesar & $\mathrm{r}=0,043$ & $\mathrm{p}=0,791$ \\
\hline Dosis rumatan rata-rata & $\mathrm{r}=-0,007$ & $p=0,967$ \\
\hline $\begin{array}{l}\text { Dosis bawa pulang (THD) } \\
\text { rata-rata }\end{array}$ & $\mathrm{r}=0,224$ & $\mathrm{p}=0,158$ \\
\hline
\end{tabular}

$(\mathrm{p}=0,158$ atau $\mathrm{p}>0,05)$ dengan korelasi sangat lemah $(\mathrm{r}=0,224)$ terhadap nilai retensi.

Pada dosis rumatan terkecil, menunjukkan ada hubungan yang signifikan $(\mathrm{p}=0,036$ atau $\mathrm{p}<0,05)$ dengan korelasi cukup $(r=-0,328)$ antara dosis rumatan terkecil terhadap nilai retensi. Pada hasil penelitian ini menunjukkan bahwa pemakaian dosis besar pada dosis rumatan terkecil maka waktu retensinya semakin pendek dengan nilai $(r=-0,328)$ yang artinya bahwa pemakaian dosis tinggi pada dosis rumatan terkecil terdapat kemungkinan risiko pasien untuk putus obat (metadon) akan semakin besar. Penelitian lain yang sejalan dengan penelitian ini telah dilakukan oleh Liu et al., yang menunjukkan adanya hubungan antara dosis dengan retensi pasien terapi metadon ${ }^{(17)}$. Penelitian Huissod et al., juga menunjukkan adanya hubungan antara dosis dengan retensi pasien terapi metadon. Pasien yang menerima dosis harian $50 \mathrm{mg}$ /hari atau lebih cenderung lebih lama berada dalam terapi metadon ${ }^{(18)}$.

Dosis awal dalam penelitian ini tidak ada korelasi dosis awal terhadap nilai retensi. Hal ini sejalan dengan penelitian yang dilakukan Pahlemy, yang menyatakan tidak ada hubungan dosis awal metadon dengan retensi pasien PTRM $(\mathrm{p}=0,895)^{(11)}$. Dosis rumatan terbesar dalam penelitian ini adalah 100 $\mathrm{mg} /$ hari. Pada penelitian ini tidak ada korelasi dosis rumatan terbesar terhadap nilai retensi. Terdapat perbedaan penelitian yang dilakukan Pahlemy, yaitu menunjukkan hubungan yang bermakna antara dosis 
rumatan terbesar dengan retensi $(p=0,000)$. Dosis yang diberikan pada dosis rumatan terbesar adalah $\geq 100 \mathrm{mg}$ dimana memiliki kemungkinan bertahan dalam terapi $\geq 1$ tahun yaitu 3,5 kali lebih besar dibandingkan pasien dengan dosis terbesar $<100 \mathrm{mg}$.

Peningkatan dosis sangat menguntungkan bagi pasien karena dapat meningkatkan retensi terapi ${ }^{(11)}$. Hal ini sejalan dengan penelitian yang dilakukan Rahayu dan Syarif, menunjukkan pasien dengan dosis $\geq 60 \mathrm{mg} /$ hari memiliki kecenderungan untuk lebih lama menjalani terapi rumatan metadon ${ }^{(13)}$. Pada penelitian ini tidak ada pasien yang mendapatkan dosis $\geq 100 \mathrm{mg} /$ hari sedangkan pasien yang mendapatkan dosis $\geq 60 \mathrm{mg} /$ hari yaitu 9 pasien $(65 \mathrm{mg} ; 67,5 \mathrm{mg} ; 70$ mg; $80 \mathrm{mg}$; $90 \mathrm{mg}$; $95 \mathrm{mg}$; dan $100 \mathrm{mg}$ ).

Dosis rumatan rata-rata dalam penelitian ini tidak ada korelasi dosis rumatan rata-rata terhadap nilai retensi. Hal ini sejalan dengan penelitian yang dilakukan Pahlemy, yang menyatakan tidak ada hubungan dosis rumatan metadon dengan retensi pasien PTRM $(\mathrm{p}=0,103)^{(11)}$. Berdasarkan hasil wawancara yang dilakukan, pasien yang mendapatkan dosis rendah dan memiliki retensi kurang disebabkan karena merasa dengan pemberian dosis yang rendah justru tidak mencegah gejala putus obat ${ }^{(12)}$. Pada dosis rumatan rata-rata dengan retensi menunjukkan pasien dengan dosis rumatan rata-rata $\geq 60 \mathrm{mg} /$ hari mempunyai proporsi lebih besar $(51 \%)$ berada dalam terapi $\geq 1$ tahun dibandingkan dengan pasien yang menerima dosis rumatan rata-rata $<60 \mathrm{mg} /$ hari $(39,5 \%)^{(11)}$. Pada penelitian ini pasien yang mendapatkan dosis rumatan rata-rata $\geq 60 \mathrm{mg} / \mathrm{hari}$ yaitu 5 pasien $(12,19 \%)$ dan pasien yang mendapatkan dosis $<60 \mathrm{mg} /$ hari yaitu 36 pasien $(87,81 \%)$.

Pada penelitian ini tidak ada korelasi dosis bawa pulang (THD) rata-rata terhadap nilai retensi. Hasil penelitian yang dilakukan oleh Huissoud et al., menunjukkan ada hubungan yang bermakna antara dosis bawa pulang dengan retensi $(p=0,009)$. Pasien dengan dosis bawa pulang (THD) pada awal terapi juga cenderung lebih lama pasien tinggal dalam terapi rumatan metadon. Sehingga pemberian dosis bawa pulang (THD) perlu dipertimbangkan untuk meningkatkan retensi pasien dalam PTRM ${ }^{(18)}$.

Hubungan Usia, Jenis Kelamin, Tingkat Pendidikan, Pekerjaan, Status Pernikahan, Riwayat Hukum, Riwayat Penggunaan Zat Aktif, Lama Penggunaan Opioid dan Riwayat Dosis Terlewat terhadap Nilai Retensi dengan Analisis Korelasi Spearman. Tidak ada korelasi yang signifikan antara hubungan usia, jenis kelamin, tingkat pendidikan, pekerjaan, status pernikahan, riwayat hukum, riwayat penggunaan zat aktif, lama penggunaan opioid dan riwayat dosis terlewat terhadap retensi pasien terapi rumatan metadon. Detail hubungan usia, jenis kelamin, tingkat pendidikan, pekerjaan, status pernikahan, riwayat hukum, riwayat penggunaan zat aktif, lama penggunaan opioid dan riwayat dosis terlewat dapat dilihat pada Tabel 3.

Hubungan Usia terhadap Nilai Retensi. Berdasarkan hasil analisis korelasi Spearman, menunjukkan tidak ada hubungan yang signifikan $(p=0,191$ atau $p>0,05)$ dengan korelasi sangat lemah $(\mathrm{r}=0,208)$ antara usia terhadap nilai retensi. Pada penelitian ini usia pasien terbesar yang berada dalam terapi rumatan metadon $\geq 1$ tahun adalah usia 26-35

Tabel 3. Hubungan usia, jenis kelamin, tingkat pendidikan, pekerjaan, status pernikahan, riwayat hukum, riwayat penggunaan zat aktif, lama penggunaan opioid dan riwayat dosis terlewat terhadap nilai retensi dengan analisis korelasi Spearman.

\begin{tabular}{llll}
\hline & Deskripsi & Nilai $\mathrm{r}$ & Signifikansi \\
\hline Usia & &
\end{tabular}

17-25 tahun

26-35 tahun

$$
r=0,208 \quad p=0,191
$$

36-45 tahun

\section{Jenis Kelamin}

Laki-laki

Perempuan

$$
r=-0,191 \quad p=0,231
$$

\section{Tingkat Pendidikan}

Tamat SMP

Tamat SMA

Tamat Sarjana

Status Pernikahan

Menikah

Belum menikah

$r=-0,016$

$\mathrm{p}=0,921$

Cerai

Riwayat Penggunaan Zat

Aktif

Penggunaan 1-3 zat aktif

Penggunaan 4-6 zat aktif

Penggunaan 7-9 zat aktif

Lama Penggunaan Opioid

$\leq 5$ tahun

5- 10 tahun

$\mathrm{r}=0,196$

$\mathrm{p}=0,218$

$\geq 10$ tahun

Riwayat Dosis Terlewat

Tidak ada dosis terlewat

Dosis terlewat 1-2 hari

berurutan

Dosis terlewat 3-4 hari

$$
r=0,241
$$$$
\mathrm{p}=0,129
$$

Dosis terlewat $\geq 4$ hari

berurutan 
tahun yaitu $60,98 \%$. Hal ini sejalan dengan penelitian yang dilakukan Pahlemy, menemukan sebagian besar pada usia $25-35$ tahun adalah $68,4 \%^{(11)}$ sedangkan penelitian yang dilakukan Rahayu dan Syarif, berusia $>30$ tahun adalah $72,3 \%$ dimana hasil analisis menunjukkan umur tidak berhubungan dengan retensi pasien terapi rumatan metadon $p=0,445^{(13)}$.

Hubungan Jenis Kelamin terhadap Nilai Retensi. Berdasarkan hasil analisis korelasi Spearman, menunjukkan tidak ada hubungan yang signifikan $(p=0,231$ atau $p>0,05)$ dengan korelasi sangat lemah $(\mathrm{r}=-0,191)$ antara jenis kelamin terhadap nilai retensi. Pada penelitian ini jenis kelamin terbesar adalah lakilaki yaitu sebesar $95,20 \%$. Hal ini sejalan dengan penelitian yang dilakukan Pahlemy, menemukan sebagian besar jenis kelamin pasien adalah laki-laki $(86,6 \%)^{(11)}$, penelitian Aprilya dkk., adalah laki-laki $(94,7 \%)^{(12)}$, dan penelitian Rahayu dan Syarif adalah laki-laki $(84,5 \%)^{(13)}$.

Hubungan Tingkat Pendidikan terhadap Nilai Retensi. Berdasarkan hasil analisis korelasi Spearman, menunjukkan tidak ada hubungan yang signifikan $(p=0,490$ atau $p>0,05)$ dengan korelasi sangat lemah $(\mathrm{r}=-0,111)$ antara tingkat pendidikan terhadap nilai retensi. Pada penelitian ini tingkat pendidikan terbesar adalah tamat SMA sebesar $82,92 \%$. Hal ini sejalan dengan penelitian yang dilakukan Pahlemy, yang menemukan sebagian besar pendidikan adalah SMA $(70,6 \%)^{(11)}$ sedangkan penelitian yang dilakukan Aprilya dkk., adalah SMA $(69,3 \%)^{(12)}$.

Hubungan Pekerjaan terhadap Nilai Retensi. Pada penelitian ini semua pasien yang mengikuti program terapi rumatan metadon (PTRM) di RSJ Menur Surabaya adalah bekerja (100\%). Pada saat pengambilan data diketahui bahwa pasien di RSJ Menur ini sudah dalam kondisi yang stabil. Hasil penelitian ini sejalan dengan penelitian yang dilakukan Pahlemy, yaitu pasien yang bekerja sebesar $71 \%{ }^{(11)}$.

Hubungan Status Pernikahan terhadap Nilai Retensi. Berdasarkan hasil analisis korelasi Spearman, menunjukkan tidak ada hubungan yang signifikan $(\mathrm{p}=0,921$ atau $\mathrm{p}>0,05)$ dengan korelasi sangat lemah $(r=-0,016)$ antara status pernikahan terhadap nilai retensi. Pada penelitian ini status pernikahan terbesar adalah menikah sebesar 75,61\%. Hal ini sejalan dengan penelitian yang dilakukan Aprilya dkk., menemukan sebagian besar status pernikahan adalah menikah $(91,9 \%)^{(12)}$ sedangkan penelitian yang dilakukan Rahayu dan Syarif adalah menikah $(58,7 \%)^{(13)}$. Berbeda dengan penelitian yang dilakukan Pahlemy, yaitu dengan status tidak menikah $58,0 \%{ }^{(11)}$.

Hubungan Riwayat Hukum terhadap Nilai Retensi. Pada penelitian ini semua pasien yang mengikuti PTRM di RSJ Menur Surabaya adalah tidak ada riwayat hukum (100\%). Pada saat pengambilan data diketahui bahwa pasien di RSJ Menur ini sudah dalam kondisi yang stabil. Berbeda dengan penelitian yang dilakukan Pahlemy, yang mengatakan ada riwayat masalah hukum yaitu $68,4 \%{ }^{(11)}$.

Hubungan Riwayat Penggunaan Zat Aktif terhadap Nilai Retensi. Berdasarkan hasil analisis korelasi Spearman, menunjukkan tidak ada hubungan yang signifikan $(\mathrm{p}=0,575$ atau $\mathrm{p}>0,05)$ dengan korelasi sangat lemah $(\mathrm{r}=-0,090)$ antara riwayat penggunaan zat aktif terhadap nilai retensi. Pada penelitian ini riwayat penggunaan zat aktif terbesar adalah penggunaan 4-6 zat aktif sebesar $80,49 \%$. Jenis zat aktif yang banyak digunakan oleh pasien dalam penelitian ini adalah opioid, alkohol, tembakau, ganja, amfetamin, benzodiazepin, kokain dan halusinogen. Sedangkan pada penelitian yang dilakukan Pahlemy, riwayat penggunaan zat aktif yang banyak digunakan adalah opiat $(100 \%)$, nikotin $(64,5 \%)$, alkohol $(46,3 \%)$, amfetamin $(35,5 \%)$ dan benzodiazepin $(26 \%)^{(11)}$.

Hubungan Lama Penggunaan Opioid terhadap Nilai Retensi. Berdasarkan hasil analisis korelasi Spearman, menunjukkan tidak ada hubungan yang signifikan $(\mathrm{p}=0,196$ atau $\mathrm{p}>0,05)$ dengan korelasi sangat lemah $(\mathrm{r}=0,218)$ antara lama penggunaan opioid terhadap nilai retensi. Pada penelitian ini lama penggunaan opioid terbesar yang berada dalam terapi rumatan metadon $\geq 1$ tahun adalah pasien dengan lama penggunaan opioid $\geq 10$ tahun yaitu $78,05 \%$. Hasil penelitian ini berbeda dengan penelitian yang dilakukan Pahlemy, yang dalam penelitiannya menemukan lamanya penggunaan opiat adalah 5-10 tahun yaitu $56,7 \%^{(11)}$.

Hubungan Riwayat Dosis Terlewat terhadap Nilai Retensi. Berdasarkan hasil analisis korelasi Spearman, menunjukkan tidak ada hubungan yang signifikan $(\mathrm{p}=0,241$ atau $\mathrm{p}>0,05)$ dengan korelasi sangat lemah $(\mathrm{r}=0,129)$ antara riwayat dosis terlewat terhadap nilai retensi. Pada penelitian ini riwayat dosis terlewat terbesar yang berada dalam terapi rumatan metadon adalah pasien dengan riwayat dosis terlewat 1-2 hari berurutan yaitu 34,15\% dibandingkan pasien yang mengalami dosis terlewat 3-4 hari berurutan yaitu $9,76 \%$. Hasil penelitian ini sejalan dengan penelitian yang dilakukan Pahlemy, yang menyatakan retensi tidak berhubungan secara bermakna dengan riwayat dosis terlewat $(\mathrm{p}=0,845)$ dengan riwayat dosis terlewat $1-2$ hari berturut-turut yaitu $61,5 \%{ }^{(11)}$.

Pada penelitian ini terdapat $7,32 \%$ pasien yang mengalami riwayat dosis terlewat $\geq 4$ hari berurutan. Pasien dengan riwayat dosis terlewat $\geq 4$ hari berurutan akan mendapatkan dosis metadon separuh dari dosis sebelum terjadi dosis terlewat, dosis dinaikkan secara 
bertahap hingga mencapai dosis optimal. Pasien yang mengalami dosis terlewat $\geq 4$ hari tetapi bertahan didalam terapi disebabkan karena proses kenaikan dosis terjadi memadai sehingga dosis optimal dengan waktu yang relatif cepat dicapai sehingga tidak menimbulkan putus obat yang terkait dengan relaps penggunaan heroin.

Terdapat bermacam-macam alasan pasien yang mengalami dosis terlewat dan hal tersebut tidak ditelaah pada penelitian ini. Dengan mengetahui riwayat dosis terlewat maka pemahaman terhadap pengaruh dosis terlewat terhadap retensi akan lebih terlihat. Alasan pasien mengalami riwayat dosis terlewat disebabkan juga oleh motivasi dari pasien tersebut dalam menjalani atau mempertahankan terapi rumatan metadon. Sehingga motivasi juga dipertimbangkan dalam dosis terlewat, dimana pasien yang diberikan motivasi yang tinggi akan lebih lama bertahan pada terapi rumatan metadon.

\section{SIMPULAN}

Berdasarkan penelitian yang telah dilakukan di RSJ Menur Surabaya pada program terapi rumatan metadon, dapat disimpulkan retention rate pasien terbesar adalah 26,8\% (24 bulan); 26,8\% (36 bulan); dan 19,5\% (12 bulan). Pada dosis rumatan terkecil, menunjukkan ada hubungan yang signifikan dengan korelasi cukup $r=-0,328$ antara dosis rumatan terkecil terhadap nilai retensi. Sedangkan untuk dosis awal, dosis rumatan terbesar, dosis rumatan rata-rata dan dosis bawa pulang (THD) rata-rata tidak ada hubungan yang signifikan dengan korelasi sangat lemah terhadap nilai retensi. Tidak ada hubungan yang signifikan antara usia, jenis kelamin, tingkat pendidikan, status pernikahan, riwayat penggunaan zat aktif, lama penggunaan opioid dan riwayat dosis terlewat dengan korelasi sangat lemah terhadap nilai retensi.

\section{UCAPAN TERIMA KASIH}

Penulis ingin mengucapkan terima kasih kepada Ibu Dr. Rika Yulia Amelia, S.Si., Sp.FRS., Apt dan Ibu Dr. Yosi Irawati Wibowo, S.Si., M.Pharm., Apt yang telah banyak memberikan saran pada penelitian ini.

\section{DAFTAR PUSTAKA}

1. Indonesia KKR. Gambaran umum penyalahgunaan narkoba di Indonesia. Buletin jendela data dan informasi kesehatan. 2014.1-15.

2. Meliala A. Badan Narkotika Nasional dan jebakan kelembagaan. J Peradil Indones Teropong. 2017.5(Januari):1-8.
3. Nasional BN. Survei nasional perkembangan penyalahguna narkoba tahun anggaran 2014. 2014.

4. Indonesia MKR. Penetapan rumah sakit pengampu dan satelit program terapi rumatan metadon serta pedoman program terapi rumatan metadon. 2008.

5. Indonesia MKR. Pedoman penyelenggara program terapi rumatan metadon. 2013.

6. Nasional BN. Survei prevalensi penyalahgunaan narkoba pada kelompok rumah tangga di 20 provinsi tahun 2015. 2016.

7. Issues C. Methadone maintenance treatment. 2000.67(November):347-64.

8. Department of health N. Opioid treatment program: clinical guidelines for methadone and buprenorphine treatment. 2006.(5).

9. Treatment EM. NIH consensus statement. 1997.15(6).

10. Services H. Principles of drug addiction treatment principles of drug addiction treatment. 2012.3.

11. Pahlemy H. Hubungan dosis dan retensi pada terapi rumatan metadon multiepisode di Rumah Sakit Ketergantungan Obat Jakarta dan Rumah Sakit Umum Pusat Fatmawati. Universitas Indonesia. 2010.

12. Aprilya D, Amiruddin, Ridwan A. Hubungan faktor perilaku dengan retensi pasien program terapi rumatan metadon di Puskesmas Kassi-Kassi. 2014.

13. Rahayu T, Syarif S. Gambaran dan faktor-faktor yang berhubungan dengan retensi pasien program terapi rumatan metadon ( PTRM ) di Puskesmas Kecamatan Tebet. 2013.1-10.

14. Ward J, Hall W, Mattick RP. Role of maintenance treatment in opioid dependence. 1999.353:221-6.

15. Ippoliti DD, Davoli M, Perucci CA, Pasqualini F, Bargagli AM. Retention in treatment of heroin users in Italy, the role of treatment type and of methadone maintenance dosage. 1998.52:167-71.

16. Jamieson, Beals, Lalonde and Associates I for the, Canada $\mathrm{O}$ of $\mathrm{CDSH}$. Methadone maintenance treatment. 2002.

17. Enwu Liua, Tao Liangb, Limei Shenc, Huan Zhongc, Bing Wangc, Zunyou Wua and R, Detelsd. Correlates of methadone client retention : A prospective cohort study in Guizhou province, China. 2010.20(4):304-8.

18. Huissoud T, Rousson V, Dubois-arber F. Methadone treatments in a Swiss Region, $2001-2008$ : a registrybased analysis. 2012. 